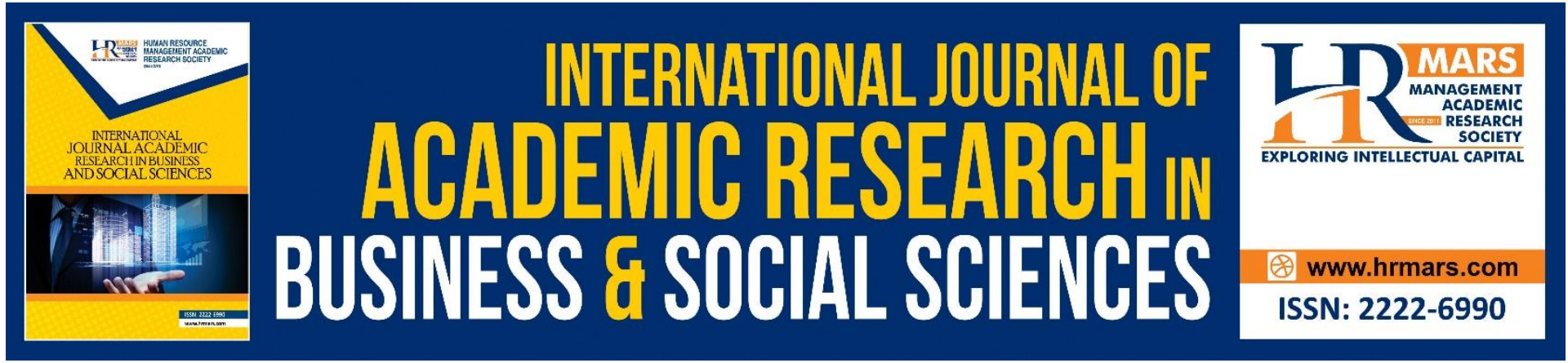

\title{
A Conceptual Framework of Ergonomic Risks Among Higher Education Lecturers While Working from Home During the Covid-19 Pandemic Crisis
}

Nor Suzila Lop, Izatul Farrita Mohd Kamar \& Nor Atiqah Mustapa

To Link this Article: http://dx.doi.org/10.6007/IJARBSS/v11-i9/11068

DOI:10.6007/IJARBSS/v11-i9/11068

Received: 19 July 2021, Revised: 21 August 2021, Accepted: 02 September 2021

Published Online: 18 September 2021

In-Text Citation: (Lop et al., 2021)

To Cite this Article: Lop, N. S., Kamar, I. F. M., \& Mustapa, N. A. (2021). A Conceptual Framework of Ergonomic Risks Among Higher Education Lecturers While Working from Home During the Covid-19 Pandemic Crisis. International Journal of Academic Research in Business and Social Sciences, 11(9), 796-810.

Copyright: (c) 2021 The Author(s)

Published by Human Resource Management Academic Research Society (www.hrmars.com)

This article is published under the Creative Commons Attribution (CC BY 4.0) license. Anyone may reproduce, distribute, translate and create derivative works of this article (for both commercial and non-commercial purposes), subject to full attribution to the original publication and authors. The full terms of this license may be seen

at: http://creativecommons.org/licences/by/4.0/legalcode

Vol. 11, No. 9, 2021, Pg. 796 - 810

http://hrmars.com/index.php/pages/detail/IJARBSS

JOURNAL HOMEPAGE

Full Terms \& Conditions of access and use can be found at http://hrmars.com/index.php/pages/detail/publication-ethics 


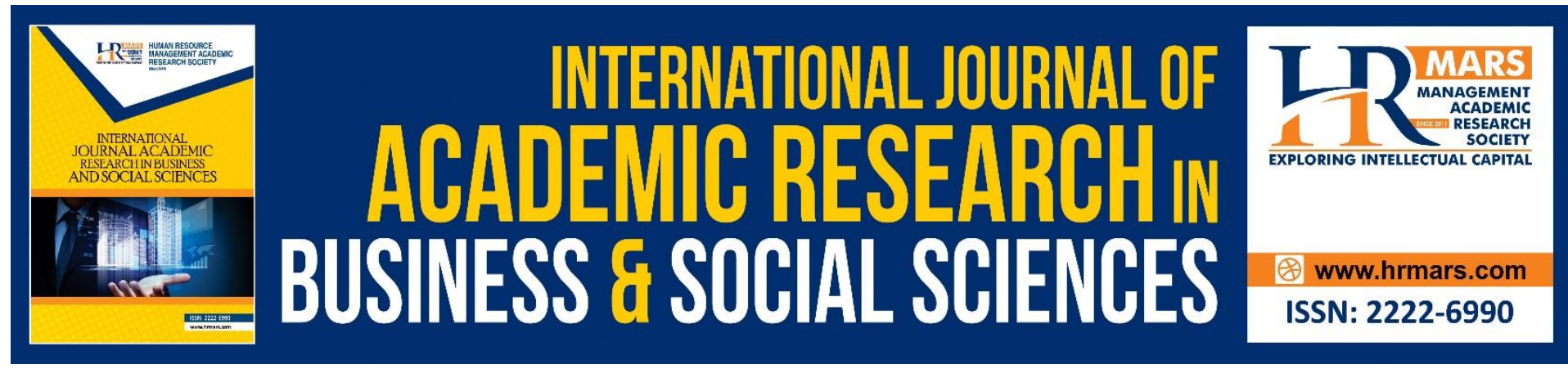

\title{
A Conceptual Framework of Ergonomic Risks Among Higher Education Lecturers While Working from Home During the Covid-19 Pandemic Crisis
}

\section{Nor Suzila Lop, Izatul Farrita Mohd Kamar \& Nor Atiqah Mustapa}

Department of Built Environment Studies and Technology, Faculty of Architecture Planning and Surveying, Universiti Teknologi MARA, Perak Branch, Seri Iskandar Campus, 32610 Seri

Iskandar, Perak, MALAYSIA.

\begin{abstract}
The pandemic Covid-19 crisis has changed our lives, where many of us spending much more time in our homes including working. The growth of working from home has changed workers' perspectives on the nature of their jobs and it will have long-lasting impacts. Previous research on the impact of Covid-19 across the world focused mostly on certain conditions like as the economic crisis, psychological trauma, and unemployment stress instead of the impact on physical health and well-being. Previous studies have already highlighted professionals are suffering from different body aches and pains due to improper ergonomics. The increasing prevalence of laptop use which has replaced the desk computer culture at work, allowing a variety of postures while working. These changing postures put the musculoskeletal system under tremendous unwanted loads and the result is bodily aches and pain with the spine bearing the utmost burnt. However, there are lack of studies focusing on lecturers in higher learning institutions, even though most educational institutions permitting workforces to work from home $(\mathrm{WfH})$ through online distance classes. Thus, two objectives are established which are; to review the WfH related activities affected to MSDs experience among workforce and to proposed a conceptual framework of ergonomics risk among higher education lecturer while WfH during the Covid-19 Pandemic Crisis. This proposed model will help the healthcare professionals and stakeholders to devise a plan, prevention, and treatment for this professional group. It is hoped that this research will benefit for well-being of people and families in Malaysia and simultaneously enhance the quality of life.
\end{abstract}

Keywords: Covid-19, Ergonomics, Musculoskeletal Disorder, Risk Factor, Work from Home.

\section{Introduction}

The new coronavirus Covid-19 was first discovered in Wuhan, China, in late 2019. The impact of the epidemic has grown in line with the rapid development of the world. This situation affects many people especially employees i.e., professional groups that have been forced to stay at home and work due to inability of cure and vaccine for the same. Countries have been under lockdown since mid-March 2020. Restrictions on offices and workplace opening and functioning are being followed since then. The Ministry of Higher Education 
(MOHE) ordered all universities to conduct online distance learning. Face-to-face classes and physical interaction with each other are also not allowed among students and lecturers at this time. Thus, students are obligatory to learn from home and adopt online distance learning methods (ODL). A similar situation occurred to lecturers where they were asked to do ODL and work from home. This is to ensure that the higher education system can continue to operate as usual and function more efficiently (Hasnizawati et al., 2020).

ODL, according to Allam et al (2020), is a teaching style in which students complete their studies anywhere because they are not physically obliged to attend lecture sessions. It is also possible to do so by fully utilising the internet network to conveniently access courses via a laptop or mobile phone (Hussin et al., 2012; Kenny \& Zhang, 2010). Furthermore, there are numerous stable and free platforms for lecturers and students to connect, discuss, and perform the teaching and learning process electronically, including Google Classroom, Google Meet, webinars, Tutor Room, and others.

This situation required the higher education lecturers using the laptop or desk computer in long duration. This may lead to MSDs due to poor posture adopted results in body pain such as in the back, neck, wrists, shoulders, knees, and ankles (Singh et al., 2020). In other conditions, Dunstan et al (2013) discovered that those who spend excessive time sitting during working and studying can cause someone is experiencing obesity, type 2 diabetes, cancer, and cardiovascular disease. While MSDs is one of the health problems which can be caused by the workforce. Work-related to musculoskeletal disorders signed by general chronic pain (Condrowati et al., 2020). Physical workload or force, repetitiveness, awkward posture, and seniority at the workplace were the most frequent factors which were found in previous studies.

Based on the epidemiological study, an occupational factor potentially increased the risk of musculoskeletal disorders. The frequency of musculoskeletal complaints differed considerably between different occupational groups (Bao et al., 2000). Therefore, different occupational factors may lead to different of MSDs pain. Many studies have been conducted on the identification of musculoskeletal disorders among workers from different occupation. Moreover, study also focused to the professional groups such as IT professionals. However, none of studies focused on the musculoskeletal disorders pain among higher education lecturers. Therefore, this is crucial to develop a conceptual framework of Ergonomic Risks among higher education lecturers during the pandemic Covid-19 crisis in order to improve negative health outcomes occurred to this professional group.

\section{Literature Review \\ Overview of Working from Home (WfH)}

In reaction to the COVID-19 worldwide pandemic crisis, numerous countries have accepted a wide actions of control measures such as remain at home, home quarantines, advisable working from home and compliance with standard operation procedure. To comply with the instructions to stay at home, the Malaysian government has instructed most of the sectors from various industries to work from home as an alternative to reduce the spread of disease outbreaks. However, there are many challenges faced by the employees who have gone through the phase of working from home. Among them are the lack of communication technology equipment, communication barriers and blur with the responsibilities for work and family. In fact, Messenger \& Gschwind (2016) explained that the concept of WfH has long been practiced since 1973 as it has been known as "telework" or "telecommuting". 
$\mathrm{WfH}$ has been characterized in different terms over the four decades, specifically in accessible work, flexible work environment, telework, working from home, e-working. These terms allude to the capacity of employees to work in adaptable working environments, particularly at home by utilizing innovation execute work tasks (Gajendran \& Harrison 2007; Grant et al. 2019). While, Lina and Nantapong (2020) mentioned that both employers and employees can benefit from $\mathrm{WfH}$. The benefits are includes preventing from office legislative issues, utilizing less office space, boosted some motivation, better gender diversity in terms of women's career, job satisfaction, better workforces due to the less employees' absence and turnover and better productivity (Mello, 2007; Robertson et al., 2003). Nevertheless, Purwanto et al. (2020) revealed that $\mathrm{WfH}$ has a few shortcomings for instance employees is burdened to pay for utilities and internet bills themselves. Whereas, Collins and Moschler (2009) has discovered that workers were isolated from their co-workers in carrying out the duties.

Nowadays, WfH has become a priority policy for most governments to cope with the pandemic situation. In doing so, the policies must be fair for both employers and employees as there will be some consequences for the two groups in one way or another.

\section{Issues of Working from Home during the Covid-19 Pandemic Crisis on Health Effects}

In the context of Malaysia, the first recorded case of COVID-19 was in January 2020. At that time, the numbers of cases were not much and limited to tourist. Subsequently, in March 2020, local outbreaks started to appear. The spiritual gathering was identified as the main cluster that triggers local outbreaks. From time to time, the COVID-19 cases becoming more acute and the data show an increase in both local and exported cases to neighboring countries. Within weeks, Malaysia had recorded the highest number of COVID-19 cases contagion in Asia. Accordingly, "Movement Control Order" (MCO; i.e., lockdown) has been declared nationwide on 18 March 2020. MCO was seen as one of the Malaysian government's actions in controlling the virus outbreak with aimed reduce COVID-19 transmission and "flattening the curve". Quarantining of infected people, social distancing and wearing masks were also been implemented as a local outbreak plan to prevent the virus from spreading quickly nationwide.

The COVID-19 pandemic has caused a sudden shift in work scenario completely. Quarantines, movement restriction and gatherings restraint, and 'stay at home' directives have compelled people to adapt to the new norms of working and this situation causes the increment of the number of people who are working remotely from their homes or other nontraditional workspaces. The COVID-19 context carries several specificities. First, the abrupt shift to teleworking could not have been predicted by workers or employers, so the safety of the home working environment has not necessarily been guaranteed. People who working from home easy to be exposed to injuries associated with the home environment or risks of MSDs associated with improper workstations. Second, in many organisations telework has temporarily switched from the exception to the rule.

The COVID-19 health emergency has brought about unexpected changes in working life. Work from home policy has been implemented in a way to minimize physical contact among individuals and at the same time to restrict new infections. The workers carry out their work without being at a specific place so-called office, solely depending on the use of technological tools (Eurofound \& the International Labour Office, 2017). It has probably been the first experience for the most remote workers. Although this home working is felt to provide many benefits to employees and employers, however, there are shortcomings in terms of 
performance monitoring, the cost of working from home, communication problems, there is no clear separation between homework and work, and it does not fit all jobs (Susan M. Heathfield, 2021).

The home environment is likely to be faulty in many respects compared to the workplace. The unavailability of ergonomically designed office furniture or workstation at home may hinder the adoption of a healthy body posture and may trigger the onset of musculoskeletal disorders (MSDS) (Malchaire et al., 2001; Phedy \& Gatam, 2016). Working in a sedentary position for a long time periods may increase the risk of neck and/or low back pain (LBP) (Celik et al., 2018; Li et al., 2020). In other circumstances, working from home may trigger mental health issues such as stress, anxiety, and isolation that eventually could affect job effectiveness, well-being, and work life balance (Erick \& Smith, 2011; Rahimi et al., 2018). According to Bouziri et al. (2020) one of the effects of working from home is risks associated with home working environment. He asserted that this situation will increase the risks of MSDs which associated with the workstation condition.

\section{Introduction to Ergonomics}

Ergonomics is usually associated with humans and their jobs. Ergonomics studies human behavioral, psychological, and physiological capabilities and limitations in a broader sense. According to Brooks (1998), those who are involved in the field of ergonomics will tend to arrange for a new work environment or adapt the existing environment according to the capabilities and limitations of human. In specific, the term ergonomics originates from the Greek words ergos meaning "work" and nomos meaning "law" or study of". Industrial ergonomics, and occupational biomechanics, is a discipline that focuses on the physical aspects of labor and human capabilities such as force, posture, vibration, and repetition. (Tayyari, 1997).

On the other words, ergonomics is a broad science that encompasses a wide range of factors that can affect a worker's health and well-being. Ergonomics factors consist of lighting, noise, temperature, vibration, heavy lifting, repetitive motion, workstation design, tool design, machine design, furniture design, and footwear. These factors can lead to the occurrence of injuries or related problems leading to musculoskeletal disorders (MSDs). Musculoskeletal disorders (MSDs) also include injuries and abnormalities of the neurological system and soft tissues such as muscle, tendons, ligaments, joints, and cartilage. As stated by Cameron (1996), severe MSDs can harm almost all tissue, including nerves and tendon sheaths, which frequently involve several body parts such as upper and lower back and arms.

\section{Musculoskeletal Disorders (MSDs)}

The term "Musculoskeletal disorder" according to Schneider (1997), encompasses a wide spectrum of inflammatory and degenerative disorders affecting the muscles, tendons, ligaments, joints, peripheral nerves, and supporting blood vessels. Musculoskeletal Disorders (MSDs) are common in most countries, which involve high costs and affect quality of life. Although they are not caused by work alone, however, they constitute for a significant proportion of all work-related illness in many countries. According to Lee and Migliaccio (2016), MSDs is a condition characterised by pain, joint stiffness, disability, functional impairment and reduced quality of life. While Farlex (2017) defined the MSDs as the disorders of the muscles, nerves, tendons, ligaments, joints, cartilage and spinal disk; it may also in compass work-related injuries. 
In the situation of movement control order (MCO), the change of the work from the office to be work from home is worried to trigger musculoskeletal disorders. For example, the people who usually work from office have the chair which has set based on the ergonomic standard. When they have to work from home, the people usually sit on the chair which they have in the home, so that it does not appropriate with the ergonomic standard so that musculoskeletal disorder is possible experienced by the workers. Condrowati (2020) in their study revealed that $86.3 \%$ of the workers working from home experience MSDs during last 12 -month where $12.6 \%$ of the workers visit the doctor because of MSDs.

\section{Ergonomic Risk Factor (ERF) Contribute to MSDs}

In most situations, risk factors are related to occupational activities, actions, or conditions that increase the risk of musculoskeletal injury, as well as ergonomics, making them more difficult to maintain this balance and increasing the risk of developing MSDs in some people. Moreover, exposure to risk factors serves as an early warning sign of more serious problems that can result in more severe damage to the body muscle. Additionally, long term exposure to risk factor will decrease the value of life. Ergonomic risk factors (ERF), on the other hand, is a situation in which anything was done on purpose or by mistake that could contribute to ergonomics risk, which could be harmful to a worker's health and wellbeing. In Covid-19 pandemic crisis situations, employees who are directed to work from home tend to experience health problems primarily related to MSDs. This is due to uncomfortable workplace conditions and not ergonomic. Based on the epidemiological study by Malchaire et al. (2001), physical workload or force, repetitiveness, awkward posture, and seniority at the workplace were the most frequent factors which were found in the studies. The factors are statistically significantly more than $50 \%$ triggered the musculoskeletal disorder of neck, shoulder, and back region. Celik et al. (2018) also conducted a survey on the workers aims to determine musculoskeletal disorders and the factors that caused the problems. The results revealed that the workers experienced the problem in the lower back with $55.1 \%$, neck with $52.5 \%$, and upper back with 53\%. Besides, the results revealed that sitting at the desk for a long time, the chair only supported the lumbar and the arms, the distance between mouse and keyboard little bit far, the head inclined at $45^{\circ}$ when working, not doing the exercise in daily life, and stress in the workplace become the factors which triggered musculoskeletal disorders. These results indicate that long-term ergonomic risk factors have contributed to MSDs of the workers.

Understanding and awareness of the negative features of ERF are crucial and essential before solutions to the problems can be identified, and they must be given priority (Jaffar et al., 2011). Lifting heavy goods, bending, reaching aloft, pushing and dragging large loads, working in uncomfortable bodily positions, and performing the same or similar duties repetitively are all risk factors for workers in a various industries and occupations. In addition, workers are more likely to develop injuries if they are exposed to the risk factors that ultimately cause to MSDs. According to OSHA (2000), the types of ergonomic risk factors are repetition, awkward posture, force, contact stress, vibration, static loading and extreme temperature. Its exposure is an early warning of progressively to cause more serious problems such as symptoms and physical signs that can bring to serious injury.

\section{Research Methodology}

An in-depth and comprehensive literature review is conducted in this research. It critically discusses and reviews the theoretically on the related activities that effect health 
(MSDs) while working at home. Based on the reviews, the proposed conceptual framework is established. Further study is planned to be conducted by comprehensive empirical research using a quantitative research design.

\section{Literature Findings}

\section{A Review of Contributing Factors to MSDs experience by Workers Working at Home}

Table 1 shows some evidence from the previous research concerning physical health issues, MSDs related to working at home. Overall, from the table, it can be seen that most of the research has consistent results whereby work or activity related to the computer has causes lower back and neck pain. Apart from lower back and neck pain, a study by Bachtiar et al. (2020) has revealed the other two parts of the body that experienced MSDs during work from home are shoulder and upper back pain. It is due to the poor postures and prolonged sitting in front of screen. In addition, all the researches stated that seated position and prolonged sitting have triggers MSDs especially to lower and upper back. It can be explained by most of the researchers that, do not have proper furniture or unavailability of ergonomically designed computer station at home can lead to poor and awkward postures and simultaneously can affect MSDs. Consequently, they experience to have neck, shoulder, lower and upper back pain. Furthermore, according to Moretti (2020), person with MSDs pain possibility to have a low job satisfaction. It is notable that providing a suitable workstation at home that applies ergonomic design is needed as it is a way to prevent MSDs and the same time to promote physical health of workers.

Table 1. Review on related activities while working from home that affect MSDs

\begin{tabular}{|c|c|c|c|c|}
\hline $\begin{array}{l}\text { Variables/ } \\
\text { Researcher }\end{array}$ & $\begin{array}{l}\text { Work from Home } \\
\text { Related Activities }\end{array}$ & MSDs Effected & $\begin{array}{l}\text { Part of the } \\
\text { body }\end{array}$ & $\begin{array}{l}\text { Ergonomic risk } \\
\text { Factor }\end{array}$ \\
\hline $\begin{array}{l}\text { Moretti et } \\
\text { al. (2020) }\end{array}$ & - Computer related & $\begin{array}{l}\text { - Lower back } \\
\text { and neck pain }\end{array}$ & $\begin{array}{l}\text { - Lower back } \\
\text { and neck }\end{array}$ & $\begin{array}{l}\text { - Poor postures } \\
\text { and static } \\
\text { position }\end{array}$ \\
\hline $\begin{array}{l}\text { Bachtiar et } \\
\text { al (2020) }\end{array}$ & - Computer related & $\begin{array}{l}\text { - Neck, } \\
\text { shoulder, } \\
\text { lower back, } \\
\text { and upper } \\
\text { back pain }\end{array}$ & $\begin{array}{l}\text { - Neck, } \\
\text { shoulder, } \\
\text { lower back, } \\
\text { and upper } \\
\text { back }\end{array}$ & $\begin{array}{l}\text { - Poor postures } \\
\text { and prolonged } \\
\text { sitting }\end{array}$ \\
\hline $\begin{array}{l}\text { Argus and } \\
\text { Pääsuke } \\
\text { (2021) }\end{array}$ & - Computer related & - Neck pain & - Neck & $\begin{array}{l}\text { - Awkward } \\
\text { position }\end{array}$ \\
\hline $\begin{array}{l}\text { Gairola and } \\
\text { Pant (2021) }\end{array}$ & - Computer related & $\begin{array}{l}\text { - Lower back } \\
\text { pain }\end{array}$ & - Lower back & $\begin{array}{l}\text { - Poor postures } \\
\text { and prolonged } \\
\text { sitting }\end{array}$ \\
\hline $\begin{array}{l}\text { Geetha } \\
(2020)\end{array}$ & $\begin{array}{l}\text { - Using multiple gadgets } \\
\text { (handphone, tablet, } \\
\text { laptop). } \\
\text { - Activities involved } \\
\text { improper facility and } \\
\text { furniture. } \\
\text { - Long hours of sitting. }\end{array}$ & $\begin{array}{l}\text { - Eye } \\
\text { stress/pain } \\
\text { caused } \\
\text { during or } \\
\text { after their } \\
\text { work. }\end{array}$ & $\begin{array}{l}\text { - Eye } \\
\text { - Neck, } \\
\text { shoulder, } \\
\text { wrist and } \\
\text { back. } \\
\text { - Lower back }\end{array}$ & $\begin{array}{l}\text { - Contact stress } \\
\text { - Awkward } \\
\text { postures } \\
\text { - Static or } \\
\text { sustained } \\
\text { postures }\end{array}$ \\
\hline
\end{tabular}




\begin{tabular}{|c|c|c|c|c|}
\hline & & $\begin{array}{l}\text { - Pain in } \\
\text { different } \\
\text { body parts. } \\
\text { - Lower back } \\
\text { pain }\end{array}$ & & \\
\hline $\begin{array}{l}\text { Tesfaye et } \\
\text { al. (2020) }\end{array}$ & $\begin{array}{l}\text { Computer related } \\
\text { activities: } \\
\text { - Sitting or standing in a } \\
\text { restricted space (in } \\
\text { front screen) for long } \\
\text { hours without changing } \\
\text { positions per day. } \\
\text { - When working with the } \\
\text { neck bent without } \\
\text { support, bent wrist, } \\
\text { working with the back } \\
\text { bent without support, } \\
\text { for two or more hours. } \\
\text { - Work that involves } \\
\text { repeating the same } \\
\text { motion with less than } \\
\text { 30s or no variation } \\
\text { every few seconds for } \\
\text { two or more hours per } \\
\text { day. }\end{array}$ & $\begin{array}{l}\text { - Neck and } \\
\text { shoulder pain } \\
\text { - Neck and } \\
\text { shoulder pain } \\
\text { - Neck and } \\
\text { shoulder pain }\end{array}$ & $\begin{array}{l}\text { - Neck } \\
\text { - shoulder }\end{array}$ & $\begin{array}{l}\text { - Statis or } \\
\text { sustained } \\
\text { postures } \\
\text { (prolonged } \\
\text { positions). } \\
\text { - Awkward } \\
\text { postures } \\
\text { - Repetitive } \\
\text { motions }\end{array}$ \\
\hline $\begin{array}{l}\text { Evina et al. } \\
(2020)\end{array}$ & $\begin{array}{l}\text { - Uncomfortable of the } \\
\text { table and chair design } \\
\text { at home. }\end{array}$ & $\begin{array}{l}\text { - Ligaments, } \\
\text { muscles, } \\
\text { nerves, } \\
\text { joints, } \\
\text { tendons, and } \\
\text { the spine } \\
\text { pain. }\end{array}$ & $\begin{array}{l}\text { - Neck, } \\
\text { shoulder, } \\
\text { back and legs }\end{array}$ & $\begin{array}{l}\text { - Awkward } \\
\text { postures, } \\
\text { bending }\end{array}$ \\
\hline $\begin{array}{l}\text { Johan et al. } \\
(2020)\end{array}$ & $\begin{array}{l}\text { - Smartphone user is in a } \\
\text { seated position under } \\
\text { ambient light } \\
\text { conditions }\end{array}$ & $\begin{array}{l}\text { - Neck, trunk, } \\
\text { lumbar spine, } \\
\text { and upper } \\
\text { limbs pain. }\end{array}$ & $\begin{array}{l}\text { - Neck, trunk, } \\
\text { lumbar spine } \\
\text { and upper } \\
\text { limbs. }\end{array}$ & $\begin{array}{c}\text { - Awkward } \\
\text { postures }\end{array}$ \\
\hline $\begin{array}{l}\text { Naomichi et } \\
\text { al. (2020) }\end{array}$ & $\begin{array}{l}\text { Not practicable in } \\
\text { computer position. }\end{array}$ & $\begin{array}{l}\text { - Neck } \\
\text { pain/stiffness } \\
\text { and low back } \\
\text { pain. }\end{array}$ & $\begin{array}{l}\text { - Neck and low } \\
\text { back. }\end{array}$ & $\begin{array}{c}\text { - Awkward } \\
\text { postures }\end{array}$ \\
\hline
\end{tabular}

Furthermore, the implementation of $\mathrm{WfH}$ is expected to disrupt and reduce the chain of the spread of the COVID-19 disease. However, there are several challenges associated with $\mathrm{WfH}$, which include the work environment at home. Geetha (2020) reported that using multiple gadgets at home such as handphone, tablet and handphone can caused contact stress that influenced to the eye stress/pain during or after their work. In addition, the lack of a working environment design at home as compared to a professional office set up gives effect the pain in different body parts due to the awkward postures. Besides that, she has 
demonstrated that upper extremity disorders such as shoulders and necks are prevalent in jobs performed in prolonged sitting positions.

While Tesfaye et al. (2020) revealed that the static postures like sitting or standing in a restricted space for two or more hours without changing positions per day (prolonged positions) has been confirmed as neck and shoulder pain. Moreover, awkward postures when working with the neck bent without support, working with a bent wrist, working with the back bent without support, squatting, and kneeling for two or more hours also gives effect to the neck and shoulder. Besides that, the repetitive work that involves repeating the same motion with less than 30 second or no variation every few seconds for two or more hours per day also give impact to the neck and shoulder.

Evina et al. (2020) explained that one of the major factors causing the occurrence of musculoskeletal disorders likes ligaments, muscles, nerves, joints, tendons, and the spine, which usually occurs on the neck, shoulders, back, and legs during work from home is the design of working tables and chairs at home. The neck is not the only joint region affected. Others joint areas such as the trunk, the lumbar spine and the upper limbs are exposed to constraints that can lead to pain, discomfort and even MSDs to the smartphone user is in a seated position under ambient light (Johan et al., 2020). Furthermore, Naomichi et al. (2020) explained that many workers complained of stiff shoulders and low back pain simultaneously due to computer position as a risk factor.

\section{Synthesis of Work from Home Activities and MSDs related experience}

Table 2 shows the synthesis on factors that contribute to MSDs for employees working at home. Most of the researches has explain that working from home is more involving computer or screen related activities either using a laptop, smartphone, or other type of gadgets. These activities are closely related to ergonomic risk factors (ERF) that ultimately contribute to MSDs among workers working at home especially to who are working onlinebased as a medium of communication.

Among the activities identified contributing to this MSDs are looking at a screen that set too low or working directly off a laptop, sitting for too long, looking down at documents or keyboard for sustained periods, keyboard/desk too high, and arms unsupported. Apart from that, poor posture is also seen as a major contributing factor to MSDs. As this will affect more sore body parts related experience such as lower back, upper back, neck, and shoulder. 
Table 2. Contributing Factors to MSDs for Workers Working at Home.

\begin{tabular}{|c|c|c|}
\hline $\begin{array}{l}\text { COMMON CONTRIBUTING FACTORS } \\
\text { (ACTIVITIES) }\end{array}$ & $\begin{array}{l}\text { ERGONOMIC RISK } \\
\text { FACTOR (ERF) }\end{array}$ & $\begin{array}{l}\text { SORE BODY PART } \\
\text { (MSDS) RELATED } \\
\text { EXPERIENCE }\end{array}$ \\
\hline $\begin{array}{l}\text { - Looking at a screen set too low or } \\
\text { working directly off a laptop. } \\
\text { - Looking down at documents or } \\
\text { keyboard for sustained periods. }\end{array}$ & $\begin{array}{l}\text { - Awkward posture } \\
\text { - Static loading }\end{array}$ & - Neck (back) \\
\hline $\begin{array}{l}\text { - Looking to one side either frequently or } \\
\text { for a sustained period. }\end{array}$ & - Static loading & - Neck (Side \& front) \\
\hline $\begin{array}{l}\text { - Keyboard/desk too high, arms } \\
\text { unsupported. }\end{array}$ & $\begin{array}{l}\text { - Contact Stress } \\
\text { - Awkward posture }\end{array}$ & - Shoulders \\
\hline $\begin{array}{l}\text { - Leaning forwards and not using } \\
\text { backrest. Inadequate lumbar support. } \\
\text { - Seat pan that is too short, providing } \\
\text { insufficient leg support. } \\
\text { - Prolonged sitting with minimal postural } \\
\text { change. }\end{array}$ & $\begin{array}{l}\text { - Awkward posture } \\
\text { - Static loading }\end{array}$ & - Lower back \\
\hline - Sustained twisted postures. & - Awkward posture & - Upper back \\
\hline $\begin{array}{l}\text { - Arm outstretched and unsupported for } \\
\text { sustained periods while clicking on } \\
\text { mouse too far to one side. }\end{array}$ & $\begin{array}{l}\text { - Contact stress } \\
\text { - Static loading }\end{array}$ & - Right arm or shoulder \\
\hline $\begin{array}{l}\text { - Frequent reaching for phone or cradling } \\
\text { phone on shoulder. }\end{array}$ & $\begin{array}{l}\text { - Repetitive } \\
\text { - Static loading }\end{array}$ & - Left arm, or shoulder \\
\hline $\begin{array}{l}\text { - Underside of thighs compressed against } \\
\text { chair seat. }\end{array}$ & - Contact stress & $\begin{array}{l}\text { - Leg discomfort, } \\
\text { swollen feet, pins and } \\
\text { needles }\end{array}$ \\
\hline $\begin{array}{l}\text { Poor posture, visual problems, glare, } \\
\text { noise, stress, high workload. }\end{array}$ & $\begin{array}{l}\text { - Awkward posture } \\
\text { - Repetitive }\end{array}$ & - Headaches \\
\hline $\begin{array}{l}\text { - Visual problems, screen too close, poor } \\
\text { image quality, glare, screen reflections. }\end{array}$ & $\begin{array}{l}\text { - Static loading } \\
\text { - Repetitive }\end{array}$ & $\begin{array}{l}\text { - Eye fatigue, temporary } \\
\text { short sightedness }\end{array}$ \\
\hline
\end{tabular}

The use of certain types of gadgets will also triggered different effects on MSDs. This will depend on the body posture during the use of the gadgets. For example, laptop; laptop position that is too high or too low will affect certain body parts such as the neck and shoulders. The visual distance between the screen and the eyes as well as the duration of time facing the screen must also be taken into account where it will cause visual problems, glare, eye fatigue, and temporary short sightedness. Such MSDs contributed from ERF such as repetitive, static loading and awkward posture. 
In a nutshell, to overcome this problem, many factors need to be considered especially in terms of the ergonomic position of the working equipment and furniture and how to adopt the correct body posture and time limit while working in front of screen. This can help in reducing the risk of MSDs experience among the workforce while working at home. Thus, there is important to identify the ERF and activities related among the workers working at home which in long term that ultimately contribute to MSDs.

\section{Proposed Conceptual Framework of WfH Activities and MSDs related experience}

Figure 1 shows the conceptual framework for this research. This framework is developed based on the literature review within the scope of $\mathrm{WfH}$ and issues of MSDs among workforce during pandemic crisis of COVID 19. This framework suggests that, in order to achieve good health and well-being (social sustainability) of individual and family, the ergonomic risk factors contributed from WfH activities that affect to the MSDs and their relationship should be given more attention to be determine.

The development of the conceptual framework as illustrated in the Figure 1 comprises of three (3) major components; issues of health related to work from home, the relationship between ergonomic risk factors and MSDs, and outcome and social benefit.

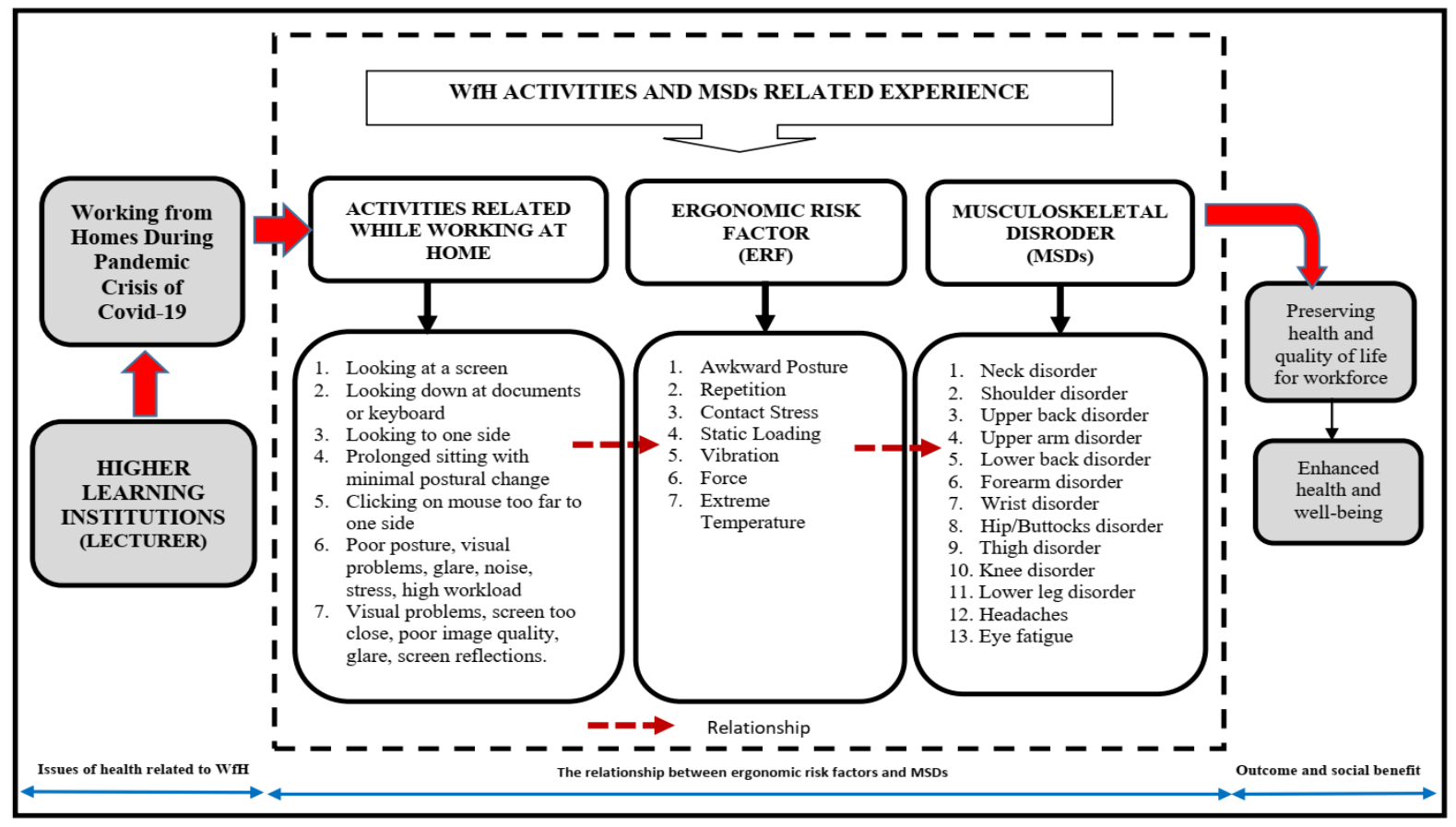

Figure 1: A Conceptual Framework of Work from Home related Activities and MSDs related experience

\section{Component 1: Issues of health related WfH}

Essentially, the framework begins by identifying the problems of working from home during the Covid-19 pandemic crisis. Based on the literature review, the most affected group were lecturers from institutions of higher learning. This group of workforce/professionals are forced by the government to conduct teaching and learning through the online distance learning system to ensure that the learning process can continue as usual. The implementation of this ODL has lasted for 3 semesters starting from March 2020 until present. In this regard, a critical literature review was conducted to identify health problems faced by the workforce during this pandemic situation. 


\section{Component 2: The relationship between ergonomic risk factors and MSDs.}

This step is to identify activities performed by the workforce (i.e. lecturer) during conducting the online distance learning (ODL) through the usage of several gadgets for instance laptop, smartphone and tablet. Besides identifying activities, this step involved the determination of ERF associated to the activities in conducting ODL. Determination of ERF is very important in order to identify the root causes of MSDs pain experience by workforce. The relationship between activities, ERF and MSDs will help in developing future ergonomic risk model. It is important to know the relationship between these factors so that appropriate action can be taken to prevent and reduce muscle pain.

\section{Component 3: Outcome and social benefits}

The future ergonomic risk model will help to enhanced and preserving health and quality of life among workforce and simultaneously enhanced health and well-being.

This conceptual framework also is essential as a guide for the development of the ergonomic risk model in enhancing health and well-being among lecturers who are force to work from home.

\section{Conclusion}

This paper anticipates to review, synthesise and develop a conceptual framework of ergonomic risks among higher education lecturer while working from home during the covid19 pandemic crisis. The development of this conceptual framework relied mostly on a literature review that focused on the issues of working from home during a pandemic crisis covid-19 from the perspective of workforce health effects. Based on the reviewed, it can be concluded that, by identifying the activities involved during implementing this ODL, ergonomic risk factors can also be identified. Thus, indirectly the health effects on body muscles (MSDs) can be easily detected. Furthermore, it can be recommended in future that, there is important to analyse the relationship between these variables in order to develop the new model. Therefore, the result of this study (i.e., conceptual framework) would provide an insight to the government and it can form the basis of a valuable guideline developing new model for the purpose of reducing the health effect to the workforce.

\section{Corresponding Author}

Nor Suzila Lop

Department of Built Environment Studies and Technology, Faculty of Architecture Planning and Surveying, Universiti Teknologi MARA, Perak Branch, Seri Iskandar Campus, 32610 Seri Iskandar, Perak, Malaysia.

Email: norsu993@uitm.edu.my

\section{References}

Argus, M., \& Pääsuke, M. (2021). Effects of the COVID-19 lockdown on musculoskeletal pain, physical activity, and work environment in Estonian office workers transitioning to working from home. Work, (Preprint), 1-9.

Ariens, G. A., Bongers, P. M., \& Douwes, M. (2001). Are neck flexion, neck rotation, and sitting at work risk factors for neck pain? Results of a prospective cohort study. Occupational Environmental Medicine, 58, 200-207. 
Allam, S. N. S., Hassan, M. S., Mohideen, R. S., Ramlan, A. F., \& Kamal, R. M. (2020). Online Distance Learning Readiness During Covid-19 Outbreak Among Undergraduate Students. International Journal of Academic Research in Business and Social Sciences, 10(5), 575-590.

Bachtiar, F., Maharani, F. T., \& Utari, D. (2020). Musculoskeletal Disorder of Workers During Work from Home on Covid-19 Pandemic: A Descriptive Study. In International Conference of Health Development. Covid-19 and the Role of Healthcare Workers in the Industrial Era (ICHD 2020) (pp. 153-160). Atlantis Press.

Brooks, A. (1998). Ergonomics approaches to office layout and space planning. Journal of Facilities, 16(3/4), 73-78.

Celik, S., Celik, K., Dirimese, E., Tasdemir, N., Arik, T., \& İb. Büyükkara. (2018). Determination of pain in musculoskeletal system reported by office workers and the pain risk factors. International Journal of Occupational Medicine and Environmental Health, 31(1), 91111.

Condrowati, Farahdina, B., Fandita, T. M., \& Dyah, U. (2020). Musculoskeletal disorder of workers during work from home on covid-19 pandemic: A descriptive study. Advances in Health Sciences Research, 30, 153-160.

Collins, J. H., \& Moschler, J. J. (2009). The Benefits and Limitations of Telecommuting. Defense AR Journal, 16 (1), 55-66.

Cameron, J. A. (1996). Assessing work-related body-part discomfort: current strategies and a behaviorally oriented assessment tool. International Journal of Industrial Ergonomic, 18(5-6), 389-398.

Daley, W. (2016). Static Posture. [Online]. Available: http://www.ehs.iastate.eduoccupational-ergonomics-static-postures. Accessed: 7 February 2021.

Dunstan, D. W., Wiesner, G., \& Eakin, E. G. (2013). Reducing office workers' sitting time: rationale and study design for the Stand-up Victoria cluster randomized trial. $B M C$ Public Health, 13, 1057.

Eurofound and the International Labour Office. (2017). Working Anytime, Anywhere: The Effects on the World of Work; European Union: Luxembourg; the International Labour Office: Geneva, Switzerland.

Erick, P. N., \& Smith, D. R. (2011). A systematic review of musculoskeletal disorders among school teachers. BMC Musculoskeletal Disorder, 12(1), 260.

Evina, W., Adian, K., Bayu, Y. S. N., \& Widya, R. W. (2020). The ergonomics design of WorkFrom-Home Facility during COVID-19 Outbreak in Indonesia and Its Implications for Musculoskeletal. Pakistan Journal of Medical \& Health Sciences, 14(4), 1619-1622.

Farlex. (2017). Musculoskeletal disorder. [Online]. Available: http://medicaldictionary.thefreedictionary.com/Musculoskeletal+disorders. Accessed: 7 February 2021.

Gairola, A., \& Pant, G. (2021). Computers users and postural issues amid COVID-19: A study of WFH. The Pharma Innovation Journal, 10(1), 512-522.

Gajendran, R. S., \& Harrison, D. A. (2007). The Good, the Bad, and the Unknown About Telecommuting: Meta-Analysis of Psychological Mediators and Individual Consequences. The Journal of Applied Psychology 92(6), 1524-1541.

Geetha S. (2020). Workspace and postural challenges in Work from Home (WFH) Scenario. International Journal of Grid and Distributed Computing, 13(2), 12-20. 
Grant, C. A., Wallace, L. M., Spurgeon, P. C., Tramontano, C., \& Charalampous, M. (2019). Construction and Initial Validation of the e-Work Life Scale to Measure Remote eWorking. Employee Relations, 41(1), 16-33.

Hanifa, B., David, R. M., Smith, A. D., William, D., \& Kevin, J. (2020). Working from home in the time of COVID-19: how to best preserve occupational health?. Occupational Environmental Medicine, 77(7), 509-510.

Hussin, S., Manap, M. R., Amir, Z., \& Krish, P. (2012). Mobile learning readiness among Malaysian students at higher learning institutes. Asian Social Science, 8(12), 276-283.

Jaffar, N., Abdul-Tharim, A. H., Mohd-Kamar, I. F., \& Lop, N. S. (2011). A literature review of ergonomics risk factors in construction industry. Procedia Engineering, 20, 89-97.

Johan, M., Julien, J. B., \& Philippe, G. (2020). Effect of the presence or absence of upper limb support on posture when a smartphone user is in a seated position under ambient light conditions. International Journal of Industrial Ergonomics, 80, 14(4), 1619-1622.

Kenny, R. F., \& Zhang, Z. (2010). Learning in an Online Distance Education Course: Experiences of Three International Students. International Review of Research in Open and Distance Learning, 11(1), 17-36.

Lee, W., \& Migliaccio, G. C. (2016). Physiological cost of concrete construction activities. Construction Innovation, 16(3), 281-306.

Li, G., Fan, Y., Lai, Y., Han, T., Li, Z., Zhou, P., Pan, P., Wang, W., Hu, D., Liu, X., Zhang, Q., \& $\mathrm{Wu}$, J. (2020). Coronavirus infections and immune responses. Journal of Medical Virology, 92(4), 424-432.

Lina, V., \& Nantapong, B. (2020). The impact of working from home during COVID-19 on work and life domains: an exploratory study on Hong Kong. Policy Design and Practice, 4(1), 59-76.

Malchaire, J., Cock, N., \& Vergracht, S. (2001). Review of the factors associated with musculoskeletal problems in epidemiological studies. International Archives of Occupational and Environmental Health, 74(2), 79-90.

Marcus, M., Gerr, F., \& Monteilh, C. (2002). A prospective study of computer users: Il. Postural risk factors for musculoskeletal symptoms and disorders. Am J Ind Med, 41, 236-249.

Messenger, J. C., \& Gschwind, L. (2016). Three Generations of Telework: New ICTs and the (r) Evolution from Home Office to Virtual Office. New Technology, Work and Employment 3 (3), 195-208.

Mello, J. A. (2007). Managing Telework Programs Effectively. Employee Responsibilities and Rights Journal, 19(4), 247-261.

Moretti, A., Menna, F., Aulicino, M., Paoletta, M., Liguori, S., \& Iolascon, G. (2020). Characterization of home working population during COVID-19 emergency: A crosssectional analysis. International Journal of Environmental Research and Public Health, 17(17), 6284.

Naomichi, T., Masanori, O., Yoshiyuki, H., Junichi, A., \& Masaharu, K. (2020). Lifestyle and subjective musculoskeletal symptoms in young male Japanese workers: A 16-year retrospective cohort study. Preventive Medicine Report 20.

Nilles, J. M. (1988). Traffic Reduction by Telecommuting: A Status Review and Selected Bibliography. Transportation Research Part A: General, 22(4), 301-317.

Phedy, P., \& Gatam, L. (2016). Prevalence and associated factors of musculoskeletal disorders among young dentists in Indonesia. Malaysian Orthopaedic Journal, 10(2), 1-5.

Purwanto, A., Asbari, M., Fahlevi, M., Mufid, A., Agistiawati, E., Cahyono, Y., \& Suryani, P. (2020). Impact of Work from Home (WFH) on Indonesian Teachers' Performance 
during the COVID-19 Pandemic: An Exploratory Study. International Journal of Advanced Science and Technology, 29(5), 6235-6244.

Rahimi, F., Kazemi, K., Zahednejad, S., LópezLópez, D., \& Calvo-Lobo, C. (2018). Prevalence of Work-Related Musculoskeletal Disorders in Iranian Physical Therapists: A Crosssectional Study. Journal of Manipulative \& Physiological Therapeutics, 41(6), 503-507.

Robertson, M. M., Maynard, W. S., \& McDevitt, J. R. (2003). Telecommuting: Managing the Safety of Workers in Home Office Environments. Professional Safety, 48(4), 30-36.

Susan M. H. (2021). The Balance Careers. The Pros and Cons of a Flexible Work Schedule. Available online: https://www.thebalancecareers.com/advantages-anddisadvantages-of-flexible-work-schedules-1917964 (accessed on 9 February 2021).

Singh, L. P. (2020). Ergonomics for working from home during covid-19 pandemic. Ergonomics International Journal, 4(4), 1-4.

Stephen, B., Jorgen, W., Houshang, S. (2000). Prevalence of musculoskeletal disorders at workplaces in the people's republic of China. International Journal of Safety and Ergonomics, 6(4), 557-574.

Schneider, S. (1997). Musculoskeletal injuries in construction, Are they a problem? Proceeding of the 13th Triennial Congress of the International Ergonomics Association, June 29July 4, Tampere, Finland. Vol. 6, 169-171.

Tayyari, F., \& Smith, J. L. (1997). Occupational Ergonomics: Principles and applications. London, Chapman \& Hall. (Chapter 1\&19).

Tesfaye, H. M., Dawit, G. Y., \& Demis, M. G. (2020). Physical environmental and occupational factors inducing work-related neck and shoulder pains among self-employed tailors of informal sectors in Ethiopia, 2019: results from a community based cross-sectional study. BMC Public Health, 1-10. 